\title{
What does it mean to 'eat Jewishly'? \\ Authorizing discourse in the Jewish food movement in Toronto, Canada
}

\author{
ALDEA MULHERN
}

$T$ his article examines the development of 'eating Jewishly' among participants at Shoresh Jewish

Environmental Programs in Toronto, Canada. Participants at Shoresh construct and draw upon Jewish tradition in order to resolve gaps between the is and the ought of the conventional food system, and to a lesser extent, the narrower food system of kashrut. 'Eating Jewishly' re-positions religious orthodoxy as one in a set of authorizing discourses, subsuming all Jewish eating acts under one rubric. 'Eating Jewishly' thus departs from standard narratives of Jewish eating as either eating kosher, or eating traditional Jewish foods. I use a theory of authorizing discourse to show the conditions of possibility through which Shoresh develops their intervention as Jewish. I conclude that such authorization practices are a key form of productive constraint in the formation of Shoresh's lived religion, and in the formation of religion as a framework for social good.

[A] great questioning [is] happening today within our community... a questioning that is not new... a questioning that has been happening for the last 5000 years... what does it mean to eat Jewishly? ${ }^{1}$

This article examines the development of 'eating Jewishly' at Shoresh Jewish Environmental Programs in Toronto, Ontario, Canada. ${ }^{2}$ Both a practice and an idea, 'eating Jewishly' arises as a response to perceived problems in the conventional food system, and within the narrower food system of kashrut ${ }^{3}$.'Eating Jewishly' allows Shoresh to gather together diverse food practices under the rubric of a specifically Jewish approach to food and eating. This rubric simul-

1 From the plenary address of Shoresh's Food Conference, January 2013. The ellipses are original.

2 This article has been much helped by Pamela Klassen and Anna Shternshis, who offered careful reading and generous feedback, and also by the insight of the Donner Institute's anonymous reviewers, to whom I am grateful. I am also indebted by David Walsh's keen editorial eye and constructive anthropological sensibility.

3 The system of Jewish law and practice governing which foods are fit or unfit for consumption by Jews. 
taneously loosens and tightens the boundaries of religious food practice, by re-positioning religious orthodoxy as one in a set of authorizing discourses, and by unifying disparate dietary practices (and Judaisms) under a single distinction between eating 'Jewishly' and not eating 'Jewishly'. Thus, 'eating Jewishly', departs from standard narratives about Jewish food practice as either eating kosher ${ }^{4}$, or eating traditional Jewish foods. 'Eating Jewishly' opens a space for a Jewish food practice that includes both of those modes alongside others, such as food ethics.

In this article I analyse the discursive formation of 'eating Jewishly', a term which I encountered during ethnographic fieldwork with Shoresh between $20 \mathrm{I} 2$ and $2014 .^{5}$ My fieldwork consisted of participant observation and indepth interviewing for a comparative study of Jewish and Muslim participation in Toronto's food movement. Here, I focus on the orienting concepts offered during the plenary addresses at Shoresh's food conferences, as a window onto their development of 'eating Jewishly' and an opportunity to glimpse what it signifies, and why it arises. ${ }^{6}$ My interlocutors at Shoresh draw upon Jewish tradition in order to confront and resolve gaps, problems, and contradictions they perceive between the is and the ought of the way their food comes to them. I use a theory of authorizing discourse to show the conditions of possibility through which Shoresh develops their intervention as Jewish. Authorizing discourse, for

$4 \quad$ Kosher meaning fit (for consumption).

5 I investigate the term as it is cultivated at Shoresh. The Union for Reform Judaism has also used the phrase, at least as early as 2009 , to turn attention to food, to cultivate increased food-consciousness, and to encourage communal meals over just food, in solidarity with the American Conservative movement's release of a policy for ethical kashrut in 2008 (Union for Reform Judaism nd; Magen Tzedek nd). To my knowledge the term itself has not been an object of investigation in any of the scholarly literature on Jewish food. Alice Stone Nakhimovsky mentions 'eating Jewish' and 'Jewish eating patterns' in her article in the important reader on food and Judaism from the Fifteenth Annual Symposium of the Klutznick Chair in Jewish Civilization and its series 'Studies in Jewish Civilization' (Greenspoon et al. 2005), but neither phrase is the object of interrogation. 'Eating Jewish' appears only in the subtitle of Nakhimovsky's article, and in the rest of the article she uses the standard parlance of 'Jewish foods' and 'Jewish foodways'. 'Jewish eating patterns' also appears once, descriptively, to denote the historical eating patterns of Soviet Jews.

6 Shoresh, as an organization, develops and enacts 'eating Jewishly' in a wide set of programming contexts in addition to the food conferences considered here. These contexts include kollels (lit. 'gatherings' for the purpose of studying religious texts) at local synagogues and at Shoresh's new roo-acre Bela Farm, farm work retreats and work days at the Kavanah Garden, and various kinds of programming for children, families, young adults, adults and seniors. A fuller consideration of Shoresh's programming is beyond the scope of this article, but may be found in my dissertation. 
my purposes, places its object in a narrative according to which the object may achieve coherence with that narrative. I conclude that such authorization is a form of productive constraint for the formation of Shoresh's lived religion, and in particular, in the formation of religious tradition as a source for social good. ${ }^{7}$

\section{Roots: introducing Shoresh}

Shoresh Jewish Environmental Programs is a not-for-profit Jewish organization based in Toronto, Ontario, Canada. Shoresh - Hebrew for 'root' - seeks to reinvigorate Toronto's Jewish community by applying 'Jewish values' to the challenges of contemporary Canadian life. ${ }^{8}$ The organization is focused particularly on food and ecological concerns. Shoresh started in 2002 under the name Torat HaTeva, the Jewish Nature Centre of Canada (lit. 'Torah of Nature'), and was the brainchild of Alexandra Kuperman. Alexandra, who is now a board member of Shoresh, developed the idea for Torat HaTeva after her experience of teaching at the Teva Learning Centre, a Jewish environmental learning organization in the United States, when she was nineteen: Teva and other American organizations including Adamah ('Earth'), Isabella Friedman Jewish Retreat Centre, and Hazon ('Vision'), are the predecessors of Shoresh in the North American Jewish food movement. ${ }^{9}$ Shoresh was later consolidated under its new name by Risa Alyson Cooper, who has been the organization's executive director since 2008. Before Shoresh, Risa spent three years learning Jewish farming in the US at Teva, Adamah, and Isabella Friedman and returned to Toronto with the goal of connecting Jewish roots and Canadian soil. That goal is now evinced in Shoresh's slogan, 'Canadian soil, Jewish roots'. Shoresh's approach, intentionally non-sectarian in nature, has become increasingly foodand agriculture-centric in recent years as food and agriculture have proved to be powerful ways to consolidate interest in Jewish environmentalism.

Shoresh's food and agriculture approach has been productive. In 2007 Risa and two Shoresh board members together launched a Jewish CSA (Community

7 Throughout the article, I refer to ethics, social goods, and problems which people want solved. In addressing these, my aim is not prescriptive, but rather descriptive.

8 Jewish values, as my analysis will show, are gleaned from both religious texts and major Jewish thinkers, and also, importantly, from other sources including daily life.

9 As of 2014, these organizations have since come under the institutional umbrella of Hazon, and now function as its subsidiaries. A history of the 'enlarged organization' can be found on Hazon's website. A number of the women with whom I spoke during my research at Shoresh have trained with or worked for Hazon or its current subsidiaries. 
Supported Agriculture) network in Toronto, which is ongoing. ${ }^{10}$ In 2009, a year after Risa took directorship, Shoresh opened the Kavanah Garden, which hosts over I,400 program participants and produces over five hundred pounds of vegetables in a growing season. ${ }^{11}$ In 2012 , Shoresh launched an annual Food Conference, involving local Jewish academics, rabbis, and community members ranging from Orthodox Jews to Reconstructionists, members of independent minyanim, and secular Jews, and even some non-Jews, including Muslims from the Noor Cultural Centre in Toronto, who were invited to take part in a panel on the religious slaughter of food animals in Canada. Shoresh is currently cultivating the new roo-acre Bela Farm, which is already hosting programs and which is expected to be fully operational by 2016 .

I first noticed the phrase 'eating Jewishly' in the context of Shoresh's food conferences. 'Eating Jewishly' is part of Shoresh's mandate to bring Toronto Jews together to deepen community and practice, while recognizing a diversity of Jewish perspectives. In order to meet this goal, 'eating Jewishly' must be capacious enough to accommodate all of the members of the Shoresh community, not just those who keep kosher: simultaneously, it has to be specific enough to answer the needs of the organization and the community, by fostering community relationships and advancing principles of social and ecological justice. It also has to be unassailably Jewish.

\section{The (Jewish) food movement}

Shoresh derives some of its momentum from public interest in the food movement. In The New York Review of Books in 2010, Michael Pollan offers his take on the emergent (American) food movement. Pollan tells of a food movement that begins slowly in the I 970 with critiques of industrial agriculture like Wendell Berry's, and then flowers in the early 2000 s in the wake of ... food safety scandals' in the US (Pollan 20ro: np). Pollan, whose work is part of the canon of contemporary food movement literature, holds that the movement is characterized by its political nature (ibid.). Pollan's implicit criteria for the political features a range of advocacy issues central to the food movement, including

10 CSAs are one of the hallmarks of the Food Movement, and involve community members supporting a (usually local) farm by agreeing to pay a fixed amount for a box containing a quantity of that farm's produce, at fixed intervals over a harvesting season. The produce usually varies according to the harvest as different foods ripen over the season. This practice, or the box itself, is also referred to as a 'farm share', 'food share', 'vegetable box', etc.

11 From kavana, Heb. 'intention'. 
school lunch reform; the campaign for animal rights and welfare; the campaign against genetically modified crops; the rise of organic and locally produced food; efforts to combat obesity and type 2 diabetes; 'food sovereignty' (the principle that nations should be allowed to decide their agricultural policies rather than submit to free trade regimes); farm bill reform; food safety regulation; farmland preservation; student organizing around food issues on campus; efforts to promote urban agriculture and ensure that communities have access to healthy food; initiatives to create gardens and cooking classes in schools; farm worker rights; nutrition labeling; feedlot pollution; and the various efforts to regulate food ingredients and marketing, especially to kids. (Pollan 2010)

In addition to environmental, health, and ethical concerns, Pollan gestures towards positive aesthetic experiences associated with eating in the food movement, and attends to the resistance to commodification, industrialization, and consumer capitalism that is another hallmark of the movement. Pollan's article reflects the food movement, and also partly constitutes it. He is frequently cited in the Jewish food movement literature, becoming iconic because he maintains the need to connect to and experience pleasure through food, alongside his keen interest in food's ethical dimensions. He is interested in knowing where food comes from, and also shows that it is possible to intervene in the food system in order to cultivate change.

Pollan, and his characterization of the food movement, sits easily alongside the other major writers of the movement: Mark Bittman, Sarah Elton, Jonathan Safran Foer, Barbara Kingsolver, Marion Nestle, Raj Patel, Carlo Petrini, Wayne Roberts, Eric Schlosser, Vandana Shiva, Peter Singer, Alisa Smith and J .B. MacKinnon, and Karl Weber. These authors, several of whom are Jewish, have different projects but share a commitment to the cultivation of what might simply be called alternative foodways. ${ }^{12}$ Here, alternative foodways means alternatives to the now-dominant industrial model which functions as

12 The term 'foodways' has gained increased currency through the emergent field of food studies. In her introduction to a recent anthology on religion and food, Marie W. Dallam defines foodways, succinctly, twice: as arising from 'cultural communities and group behavior in relation to food and eating' and as 'a set of beliefs and practices that govern consumption' (Dallam 20I 4: xviii). Other definitions are possible, and those that specifically enumerate the stages through which food passes as it undergoes transformations from production to consumption are considerably longer. Dallam herself quickly traces the origin of the term with the New Deal writers of the I930s and through religious studies and folklore scholars in the 6os and 7os (ibid. $\mathrm{xxxnI}$ ). 
the conventional food system in North America and elsewhere. Alternative foodways are conceived as improving the quality of life of human, and nonhuman, beings by refusing the excesses of industrialization. That this desire for improvement often involves notions of the past as the source of improvement, is both something to be expected, and also something worthy of attention, as we turn to religious participation in the movement. ${ }^{13}$

The Jewish food movement intersects with the wider food movement at a number of locations, and in complex ways. As Sue Fishkoff shows in a thorough, journalistic exploration of the kosher market, many Jewish and non-Jewish Americans have understood kashrut as an alternative to the conventional food system. Fishkoff refers to the iconic Hebrew National ad campaign which states that their kosher food products 'answer to a ... higher authority' (Fishkoff 2010: 3). She explains that Americans believe that kosher food is 'better ... cleaner [and] worth the money' when compared with conventional food (ibid. 4, see also pp. 275-6). She argues that ' 86 percent of the nation's I I.2 million kosher consumers are not religious Jews' due to the 'perception ... that kosher food is cleaner, safer, better ... of higher quality ... more healthy' (Fishkoff 2010: 6, 7; similar numbers are cited in Gross 2010). Increasingly, that attitude is shifting: many of the criticisms levelled at the conventional food system generally in terms of treatment of animals, treatment of workers, environmental impact, and healthfulness, are now also levelled at the kashrut industry (ibid. passim and inf.).

Jewish faith in kashrut has been shaken by several controversies during the history of kashrut in North America. Some of these controversies have functioned to reinforce the authority of kashrut, as with the history of kosher meat fraud in the US in the twentieth century (Fishkoff 2010, Gastwirt I 974, Lytton 2013, Sarna 2004). Controversies of this kind resulted in various kinds of tightening: the inflation to glatt kosher ${ }^{14}$ as the standard for kashrut among certification agencies, an increase in oversight, the privatization of kashrut through

13 Invoking the past should be expected, because envisioning alternatives to a current system is easiest when there is an existing stock of history to draw upon. It is more difficult to imagine future alternatives. A teleology becomes more explicit when contemporaneous non-Western and non-First World societies are invoked as pre-industrial alternatives which are virtuously connected to practices constructed as 'traditional'. The tension between notions of progress and regress is useful in creating ideational space for producing alternatives, but meanwhile re-performs narratives which themselves remain problematic and pervasive cultural logics.

14 Glatt, from the Yiddish 'smooth', here refers to the smoothness of an animal's lungs, which must be examined and found to be lesion-free in order to meet this higher standard. 
kosher certification bodies, and industrial kashrut. It should be noted that this tightening offered important protections against abuse for Jews who purchase kosher food, as well as for those embedded in the production and oversight processes, relative to the self-governance system (see Lytton 2014 on the benefits of regulatory bodies relative to self-governance; cf. Hyman 1980 on the political power of women in community regulation via boycott). Other controversies have thrown light on abuses that appear to have occurred within the bounds of, or at least were deemed by certain authorities not to contravene, standards of kashrut. The most notable of these is the controversy at AgriProcessors' glatt kosher slaughterhouse in Postville, Iowa. People for the Ethical Treatment of Animals (PETA) released a video in 2004 depicting what has been construed as inhumane slaughter at AgriProcessors, before the plant itself was the object of US government immigration raids over human rights abuses in 2008, and ultimately went bankrupt (for pre-event history see Bloom 2000; for the central narrative see Gross 2010). ${ }^{15}$ These latter controversies have bolstered a larger questioning of kashrut, in both its orthodox interpretation and its industrial form, in relation to Jewish life. Such questioning has in some cases contributed to calls to abandon kashrut; in other cases, it has motivated calls for a revised, expanded, or renewed understanding of kashrut.

\section{Jewish food ethics}

The Jewish food movement, in its basic form, is concerned with finding Jewish answers to problems in the conventional food system. Insofar as it is primarily about making food choices that ultimately result in a more ethical food system (see also 'Contemporary Jewish food movement' in Most and

15 These two sorts of controversy are really of a piece. Lytton argues: 'The Postville scandal ... arose out of allegations related to labor, environmental, and financial crimes, not—notably—problems with the operation's kosher standards. Thus, while the Postville scandal offers insights into the failures of industrial meat production generally, it does not support an indictment of kosher meat certification. Of course, retail scandals involving local butchers fraudulently selling treyf beef and poultry as kosher continue to occur, although there is no evidence to suggest that these incidents reflect a fraud rate comparable to the 40 to 65 percent estimated fraud rates in New York City in the early twentieth century' (Lytton 20I4: 44n I 7). However, Lytton's estimation of the scope of Postville's challenge to kosher meat certification is unnecessarily narrow in two important ways: because it begs the question of what kashrut rules in or out, on which significant challenges to kosher certification rest, and because Orthodox authorities have indeed questioned whether the slaughter captured on film at AgriProcessors violated kashrut (Gross 2010: 80-6). 
Mulhern 20I 4; Most, forthcoming), the Jewish food movement fits well within Pollan's characterization of the wider food movement as political. ${ }^{16}$ The Jewish food movement claims key authors of the wider food movement mentioned above, especially Pollan and Safran Foer, who both allow their relationship with Judaism to emerge in their work (albeit differently, for example, with respect to pork). It also draws on Jewish theological texts, particularly those dealing with the environment, to develop its own literature. One key authorizing text of the Jewish food movement I describe is an edited volume that emerges from CCAR Press, The Sacred Table: Creating a Jewish Food Ethic (Zamore 20 I I). Sacred Table was prefigured by a sourcebook out of Hazon that outlines the basics of the movement and is descriptively subtitled 'Hazon's curriculum on Jews, food and contemporary life' (Savage and Hanau 2007). Nigel Savage, founder and president of Hazon and one of the authors of the sourcebook, also wrote the preface to Sacred Table. Sacred Table, coming out of the Reform movement, typifies the new Reform approach to food, cultivating personal spiritual experience while also deriving ethical principles from Jewish sources. ${ }^{17}$ As we will see, Zamore's Sacred Table is instructive because it dwells on the key concepts the Jewish food movement pulls from American Jewish history and biblical Jewish tradition, and because these concepts also resonate with the wider food movement.

The food movement has critiqued the conventional food system for animal mistreatment, environmental degradation, and social injustice: its Reform iteration has moved from ambivalence about kashrut, to a desire to excavate a multivalent kashrut that addresses these concerns. ${ }^{18}$ The Jewish food movement in general looks to Jewish sources for a Jewish food ethic that evades ethical problems. The Zamore text draws on biblical and rabbinic literature in order to explore and develop the key principles of a Jewish ethical tradition related to food. The key principles are bal tashchit (do not destroy), tzaar baalei chayim (the suffering of living beings- to be avoided), oshek ([financial] oppression [of a worker]- to be avoided), tzedek (justice), shimirat haguf (to guard one's

16 Additionally, the Jewish food movement is strongly aesthetic and can reveal frustration with industrial capitalism, although neither of these threads can be fully explored here.

17 To grasp the Reform movement's particular approach to kashrut and Jewish food, it is useful to begin with Gross in Zamore 20I I in particular, before the rest of the volume.

18 This is not to say that the Reform iteration of the food movement is identical with Reform Judaism. In I 885, the first of the Reform movement's Pittsburgh Platforms roundly rejected the relevance of kashrut to then-contemporary Jewish life. This position softened considerably by the time of the second Pittsburgh Platform in I 999. For more of the richness of American Reform Jewry's wrestling with kashrut see Joselit 2005, Gross 201 I (cited above), and Part One of Zamore 201 I. 
health), and tikkun olam (the repair of the world). ${ }^{19}$ Many of the articles in the volume take up one or more of these terms in order to excavate its appearance in biblical and rabbinic literature, and then apply it to contemporary cases from the food system, from cruel animal farming practices to abusive conditions for farm workers.

The nature of the relationship between the dietary laws as they have been conventionally understood, and Jewish ethical principles from the rest of halacha and Jewish tradition, is open to debate, and in the process of being debated. Questions about whether kashrut should include ethical principles; whether it is these principles, and not kashrut, that are relevant to contemporary Jewish life; or whether kashrut is necessary but not sufficient for Jews who are concerned about food, all animate Shoresh's conversations around 'eating Jewishly'. This work is done in part by constructing the discursive object 'food', and then bringing 'Jewish tradition' to bear on it.

\section{Shoresh's Jewish food values}

Following organizations like Hazon, ${ }^{20}$ Shoresh takes both an intellectual and a practical approach to its work. Shoresh staff members have strong Jewish educational backgrounds, as well as practical farming experience from the contemporary Jewish food movement and the new stream of Jewish ecological learning initiatives that are now collated as 'Jewish Outdoor, Food and Environmental Education (JOFEE) experiences'. Hazon coined the term JOFEE, publicizing it with their report, 'Seeds of Opportunity: A national study of Immersive Jewish Outdoor, Food and Environmental Education (JOFEE)' (Informing Change, 20I4). Shoresh is embracing the acronym, which fits well with the programming Risa wanted to bring to Canada in 2008. In Shoresh's programs, Jewish food is engaged in different ways, by growing and harvesting it, preparing it, reading about it, talking about it, and eating it. 'Eating Jewishly', however, is perhaps most visible when the phrase itself is used, as it has been in the plenary address at each of the Shoresh food conferences.

In her plenary address in 2012, Risa inaugurated the Shoresh Food Conference by welcoming a diverse group of participants and orienting them

19 Much the same principles are in evidence in the work of Jewish theologians from Jewish Renewal and EcoJudaism, such as Arthur Waskow and Jeremy Benstein. Because all these groups are at least semi-universalizing, and look to Jewish texts and traditions for ethical principles which bring together the environment, humans, and other living creatures, there is a good deal of overlap in the resources that they uncover. The flagship organization of the American Jewish food movement discussed earlier. 
toward a common field of vision. Risa situated the food conference within what she described as a '5000 year old conversation of what and how and when we eat' ${ }^{21}$ In so doing, she presented a concern with food to be utterly Jewish. The notion of 'eating Jewishly' was already on the table in 2012, and in 2013, that language became central: the 2013 plenary was much more explicit in its desire to simultaneously create and use the concept of 'eating Jewishly'. This article began with a quotation taken from that plenary: '[A] great questioning [is] happening today within our community... a questioning that is not new... a questioning that has been happening for the last 5000 years... what does it mean to eat Jewishly?'

With this phrasing, Risa and the organization she directs have placed the phrase 'eating Jewishly' at the heart of food and Judaism, using it to capture aspects of tradition and history which are left out by narrower categories of Jewish observance. Risa uses Hebrew terminology, mentions Shoresh's relationships with local and umbrella Jewish organizations, and speaks of 'Jewish traditions', 'Jewish values', and 'Jewish practices' that underpin Shoresh sites and activities. Shoresh events are presented as fundamentally Jewish and (yet) in principle open to all who wish to come. This presentation combines careful precision and careful generality. It is motivated by a principle of inclusion arising from Shoresh's mandate to deepen Jewish engagement across the various divides that fragment Jewish community. Developing 'eating Jewishly' is thus an exercise in developing 'Jewish'.

In the plenary, Risa asked a series of rhetorical questions that help elucidate the contours of 'eating Jewishly'. They correspond to many of the concerns of the Jewish food movement and the larger food movement generally, showing the locations of tension with conventional understandings of Jewish food practice. This portion of the plenary sheds light on the network of ideas that are involved in contextualizing food concerns as Jewish concerns. The questions occur in four clusters: eating Jewishly as eating Jewish food, eating Jewishly as keeping kosher, eating Jewishly as a practice of Jewish ethics, and eating Jewishly as engagement with the divine.

Risa begins, 'does eating Jewishly mean eating foods that are culturally Jewish?' She tells a brief story about United Bakers in Toronto, and how her Ashkenazi grandmother 'swears by' their bagels. Risa then asks, 'What if I am a vegan, gluten intolerant, Ashkenazi Jew ... can I still eat Jewishly if challah,

21 I take these quotations from Risa's plenaries at the Shoresh food conferences I attended during my fieldwork. Transcripts of the plenaries are available on the Shoresh Blog. 
matza ball soup, mandel broit, brisket, bagels with lox and cream cheese ... are not a part of my diet?' Risa is speaking to an audience to whom her juxtaposition will be familiar: for a long time Ashkenazi Jewry made up the bulk of North American Jewish culinary culture and the dishes Risa has listed are both iconically Jewish, and manifestly wheat and/or animal products (eggs, milk, or meat). These foods are both vividly Jewish, and vividly at odds with other ethical or health-related dietary restrictions that are prevalent in the food movement. ${ }^{22}$ Risa is touching on an important division occurring in the community. Not only do people who wish to eat their cultural foods find their choices radically restricted by their other dietary needs: they also may find that their ethics or their physical concerns create a separation between them and their own families at table. This is the very kind of separation which Jewish dietary law elsewhere erected between Jew and gentile.

The second cluster of questions is more complex even than the first, and is approximately twice as long. It begins, 'Does eating Jewishly mean eating foods prepared according to the traditional laws of kashrut? Who decides if something is kosher?' Risa here problematizes reliance on hekbshers, the industrial symbols of kosher oversight that appear on food labels, by invoking a past of Jewish food before industrial kashrut.

Ioo years ago, the women in our family, the keepers of the kitchen, they decided if something was kosher. They knew the butcher, the cheese monger, the baker... As our food system developed into a global food system, a system where our food is often grown/raised, packaged and prepared, out of sight, certifying agencies became important in helping consumers make informed food choices.

Having noted the benefits of access to industrial kosher certification, Risa now turns to some of the drawbacks that concern the people gathered at the conference: 'So what happens now that we are seeing a move back to smaller, locally-based food systems? For many, certified kosher has become the new standard of kosher. Can something be kosher without a hekhsher?' Not only is Risa connecting with the concerns of food movement participants who wish to eat local sustainable foods and support small local businesses; she is also giving voice to a struggle faced at Shoresh's Bela Farm: the farm will produce fresh foods that need to be prepared and preserved, like the cucumbers that will 
be pickled there, but it may be prohibitively expensive to attain and maintain kosher certification.

The third cluster of questions is the longest, nearly four times the size of the cluster about God. It is the location of a significant thread in the logic of 'eating Jewishly'. The question that Risa historicizes is a flashpoint of debate in the Jewish food movement: 'Does eating Jewishly mean eating in a way that reflects Jewish ethics and values beyond kashrut?'

[O] ur food system has changed radically in the last 60-70 years. Food today is more complicated than ever.... Some are arguing that we need to expand the definition of kosher - can we call something kosher, which literally means 'fit' to eat, if it has been grown in soil sprayed with known carcinogenic chemicals? ... [I]f we are packaging or serving it in Styrofoam? ... [I]f we know that those who helped grow or prepare our food were not paid fairly or given a safe working environment? ... [I]f the animals were raised in conditions resulting in incredible suffering?

Questioning the kosherness of carcinogens, Styrofoam, and abusive labour and animal husbandry practices is based on a fundamental inference about the relationship between kashrut and Jewish human, animal, and environmental ethics. The idea that food in particular ties together different dimensions of Jewish ethics, and indeed different kinds of Jewishness, is the heart and blood of the Jewish food intervention. That the most religiously orthodox Jewish diet today may be among the most processed, the least healthy, the most heavily packaged, and the most wasteful, is an intolerable contradiction for some in the audience, and evidence of the need for change for many others. Risa continues:

There are those who say kosher is kosher (we don't need to redefine kosher), AND that does not give us permission to willing[ly] overlook our tradition's ethical teachings when it comes to the food choices we make.

Tzedek, tzedek tirdof... justice, justice you shall pursue. Justice for those by whose hands we are fed. Justice for the earth. Justice for the non-human animals in our food system. Justice for our own bodies. Justice for those who are hungry in our community. The Torah commands us to pursue justice. Eating has become a political act. So maybe eating Jewishly means embodying the fullness of Judaism's ethical principles as they apply to our current food system. 
Risa, who keeps a kosher home and strives to eat ethically, voices the desire to hold kashrut in principle alongside Jewish ethics. Relying on the notion of tzedek, justice, Risa knits environmentalism, animal issues, and social justice issues together in the shape of food, and reveals food to be the material of politics and of ethics.

The fourth and last line of questioning is the briefest, and it is about God. God is spoken of obliquely, using language like 'ultimate Creator' and 'the divine' alongside 'energy' and 'life'.

Does eating Jewishly mean creating space for the divine at our tables? Does it mean acknowledging the role of an ultimate Creator, a unifying energy or breath of life? Does it mean saying a blessing, expressions of gratitude? According to the Talmud, it is forbidden for a person to enjoy anything of this world without a blessing, and if anyone [does] s/he commits sacrilege. ... Does eating Jewishly mean eating with intention?

Here there are hints of an individualist model for religion. God is not invoked as an inscrutable lawmaker, but as the God with whom Jews are in relationship. Awareness of God allows ordinary experiences of food (or other enjoyment) to become elevated, or to be revealed as already elevated, rather than to become debased by lack of the proper orientation. 'Eating Jewishly' is connected with intention, and intention to eat Jewishly is a cultivated orientation toward a naturalized idea of sacredness.

These rhetorical questions soften the powerful challenge that may be seen to lie within the words: not only a challenge to the authority of kashrut, arising from the historicization of it and the critique of it, but also a challenge to Jews to eat Jewishly and to become politically involved in the food system in which they are implicated as consumers, as subjects. Health, tradition, ethics, politics, and God are all invoked here, in that order, and they are all placed on our plates, manifested as a function of our food choices. Risa has also offered a way into the movement for people who are otherwise marginalized by other discourses of Jewish food as accessible only through kosher brisket or mandelbroit. Ethics and politics have been placed alongside health, tradition, and orthodox religiosity. Importantly, the questions Risa asks thus function to create space for a multiplicity of participations and a range of responses to the call to eat Jewishly.

Risa has used questions to open up the rhetorical landscape and bring diverse participants to the same field of vision. Next, Risa integrates the possibilities by grounding them in firm orienting statements, planting seeds where she has tilled: 
Jewish texts and teachings are clear - there are rules and traditions that govern our relationship with food - how we grow it, how we prepare it, how we eat it, how we share it with others. Our community has been exploring the nature of our relationship with food for over 5000 years and today is about moving that conversation forward. Which is why we have brought you all together - foodies, chefs, rabbis, farmers, students, teachers - we need everyone's voice at the table, we need to think holistically about what it means to eat Jewishly here, today.

By speaking about '5000 years' of 'rules and traditions that govern our relationship with food', Risa discursively makes food an object of Jewish tradition. In this way, kashrut is positioned beside a swathe of other, relatively less thought about, Jewish texts and traditions related to food, and these texts and traditions of the distant and recent past are constructed as related to food, from within a contemporary idiom.

\section{Authorizing 'eating Jewishly'}

Authority is navigated at Shoresh by means of discursively linking ideas and activities at Shoresh to Judaism or Jewishness, which are themselves authenticated by means of Jewish religious texts, by a broader swathe of 'Jewish thought', and also by recourse to 'Jewish tradition' which includes and transcends sacred texts (and the contradictions therein) by the unifying emphasis on things done by Jews. 23 'Eating Jewishly' means many things for those who are engaged in and by it, but it essentially designates a broadening of the field for thinking about what it means to be a Jew and to eat. It evinces a growing concern that kashrut may not be sufficient to designate even the diet of a 'good' Jew, since most Jews in North America do not 'keep kosher', but still place a great deal of importance on their identity as Jews (Lugo et al. 2013: Chapter 3). If food practice is important to identity, then it becomes of pressing concern to have food practices that enact Jewish identity. If kashrut now excludes not only most gentiles but also most Jews, then kashrut faces a problem. Shoresh's solution to such a problem must involve grounding their approach to food in narratives of Judaism, Jewishness, and Jews.

23 The recursion, turning on the question of what a Jew is, is both problematic and inevitable. 
Understanding Shoresh's cultivation of 'eating Jewishly' as the development of a lived religious foodway involves attending to what is said and done around food, but not only that: it also involves attending to the means by which things are said and done, and the conditions under which such sayings and doings are made possible and legible. Put another way, noting the lines of authority according to which Shoresh's interventions are realized helps show how their intervention works, both in terms of what it means for them, and what it means for scholars of food and religion.

In Genealogies of Religion, Talal Asad makes a set of interlocking points around authorizing discourses that I find useful for thinking about Shoresh's activities (Asad I 993) ${ }^{24}$ Asad is interested in the power relations that authorize particular practices and processes as legitimate, and I use his approach to shed light on the authorizing discourses present in our examples. While critiquing Geertz's theory of religion, Asad asks about 'the authorizing process by which "religion" is created', how 'authorizing processes represent practices, utterances, or dispositions so that they can be discursively related to general (cosmic) ideas of order' (ibid. 37). He says authorizing discourses have 'defined and created' religion not by 'establish[ing] absolute uniformity of practice' but rather by forming an overarching narrative against which behaviours and beliefs are to be measured (ibid. $37^{-8}$ and f.). Asad is not defining religion here. He is reflecting on how power works. He points to the social processes of knowing, which must construct their object, knowledge. Authoritative discourse produces a map of possibilities, and an implicit framework for evaluating those possibilities; as such, authoritative discourses warrant our attention. But where Asad says such a framework could tell truth from falsehood for medieval Christianity (ibid. 39), the framework I have discerned in 'eating Jewishly' offers a way to tell good from bad.

Asad sheds further light on authorizing discourse when speaking about Islam in the Middle East. Paying special attention to the role of orthodoxy as a gatekeeper of authorizing discourse precisely because it 'aspires to be authoritative' (Asad I993: 2 I I), he notes that:

Muslims in Saudi Arabia (as elsewhere) disagree profoundly over what orthodox Islam is, but as Muslims their differences are fought out on the ground of that concept.... the process of determining orthodoxy in con-

24 Speaking about Christianity and Islam in order to problematize the translation of nonWestern 'religions' into Western, implicitly Christian historical terms, Asad calls for an investigation of anthropology's complicity in colonial modernity. 
ditions of change and contest includes attempts at achieving discursive coherence, at representing the present within an authoritative narrative that includes positive evaluations of past events and persons. Because such authority is a collaborative achievement between narrator and audience, the former cannot speak in total freedom; there are conceptual and institutional conditions that must be attended to if discourses are to be persuasive.

(Asad I 993: 2 Io, emphasis original)

Asad reveals that part of the power of authorizing discourse is that it is constructed 'on the ground of' orthodoxy ${ }^{25}$, that is, that for the religious subjects in question, coming out on top is necessarily a matter of being right. This helps us see that one who enters into such discourse with the goal of being right is constrained by a set of possibilities for rightness. Part of being right is 'achieving discursive coherence' where the object of coherence is relevant portions of 'past events and persons'; another way to say this is tradition. In fact this points up a part of tradition that it is important to acknowledge, which is that the claim to coherence with tradition necessarily situates oneself within that tradition, and thus tradition itself is, whatever else it is, a constant re-negotiation of the past in terms of the present and of the present in terms of the past. Furthermore, the tradition, insofar as it exists at Shoresh and elsewhere, is also a collaborative achievement of the kind Asad describes. Redescription and reconceptualization, furthermore, are part of right orientation. Orthodoxy, from a constructivist perspective, is less a fact than an achievement. Asad defines orthodoxy not by opposition to change, but by the 'aspiration to authority' even in change (I 993: 2 I I). He writes:

What is involved in such changes is not a simple ad hoc acceptance of new arrangements but the attempt to redescribe norms and concepts with the aid of tradition-guided reasoning. The authority of that redescription, among those familiar with and committed to that tradition, has depended historically on how successful the underlying reasoning was judged to be. (Asad I993: 2 I I)

and

[Religious] classification forces specific questions onto people who belong to that tradition: Into which category does a given behavior fall? Is it re- 
ally new, or is it an analogue of something whose classification is not in dispute? The application of these categories to behavior ... often involves an elaborate work of reconceptualizing the context itself in ways that aim to be plausible to [an audience of one's co-religionists]. (Asad I993: 2 I 2)

Asad's claim resonates, in an explanatory register, with the patterns of authorization at Shoresh and in the Jewish food movement generally. Intensive industrial farming and animal husbandry as they appear today in North America are recent, and are radical departures from the reality of food production over most of the history of Jewish food law and tradition. Some of the differences are grand; some are troubling. The change and troubles together have been sufficient to prompt the redescription and reconceptualizing Asad describes. My interlocutors at Shoresh are troubled by a perceived disjuncture between contemporary food, ideal and practical kashrut, other parts of halacha, and their attempts to lead a Jewish life. The role of ethics in particular in Jewish law and practice has become a flashpoint in the proliferating conversation about Jews and food, presenting a problem for classification, descriptively and prescriptively, about what and how to eat. Tracing authority, here, is a matter of following which discursive threads achieve sufficient coherence across domains in order to be considered plausible, tenable, and, I would add, hopeful. ${ }^{26}$ After all, religion here is being looked to to bear the weight of truth or rightness about what a food system ought to look like. This idea that religion is a source for a reparative critique of the current conventional food system has implications that transcend the bounds of Jewish consumption and sit squarely in the realms of the public and the political.

'Eating Jewishly' is cultivated by the community at Shoresh to bring together a set of diverse eating practices under a singular rubric. It is a means of authenticating eating practices as Jewish, and in order to do so it operates within particular constraints. In enlarging the scope of legible, Jewishly-oriented eating practices from kashrut observance to 'eating Jewishly', Shoresh must describe plausible boundaries of what is Jewish. These boundaries have been described along the following lines: culturally-Jewish foods, kashrut, Jewish ethics and values, consciousness of the divine, and a horizontal understanding of 'we'. By claiming the struggle to determine what is fit to eat as a Jewish struggle, Shoresh makes space for a diversity of practices to be authorized into the body of Jewish tradition. Shoresh has responded to crisis in the conventional food economic possibility. 
system by redescribing boundaries. Underlying this work is the assumption that religious tradition has answers to offer a problematic food system which, by being too (economically) value-driven, has emptied itself of value(s). Thus, while the Shoresh response includes culture, law, ethics, God-consciousness, and community, it becomes clear that there is a particular operating assumption about religion that creates the preconditions for this response. That assumption is that religion is the right place to look, that religion can offer an ethics, that is, a system for valuing, that is ultimately right in the sense of being both true and good. Religion, constructed as tradition, is made to offer rich resources from which religious subjects can derive an ought to ameliorate is.

\section{Conclusion}

Contemporary and historical issues that could otherwise be thought separate from each other were brought together under the rubric of 'food' in Risa's plenary, in the rest of the Shoresh food conference, and in much other foodrelated programming I have participated in during my fieldwork. Seemingly disparate biblical and extra-biblical Jewish texts and traditions were connected with one another, and thereby unified, under a food lens. ${ }^{27}$ Authorizing discourse is not limited to sacred texts, but can be derived from contemporary authors and organizations who write about Jewish life, and also, by the same logic, from the experiences and concerns of the people who are present. Seen in this way, Shoresh's work in the area of 'eating Jewishly' is a complex of discourses both verbal and practical, which seek and thereby construct a Jewish matrix from which to derive solutions to the new problem of eating.

Where kashrut has moved out of the centre of discourse about Jews and food, other kinds of eating become visible alongside kashrut. 'Eating Jewishly' is about conscious or mindful eating, understood and experienced as Jewish through the connection with 'Jewish' things like Jewish texts, Jewish tradition, or God, but also Jewish authors, Jewish institutions, Jewish camps and farms, and the experiences and concerns of ordinary Jews. ${ }^{28}$ Shoresh's 'eating Jewishly'

27 These texts include dietary laws; agricultural, war, and hospitality narratives; economic, charity, and justice-related texts; medical advice; and myths about the origins and ends of human life.

28 Conscious or mindful eating may involve, for example, blessings or invocation of the divine, making ethical food choices, deliberately eating traditional or symbolic food, and so on. In practice, the presence of legibly Jewish reasons or narratives are fundamental. In my fieldwork I often heard the phrase 'eating with intention' in this connection. 
is a grassroots initiative for the horizontal authorization of diversity in lived Judaism, or lived Jewishness.

Whereas industrial and orthodox logics have together authorized the complex of industrial kashrut, this authority has been called into question by the contemporary food movement's critique of the harms of the conventional food system, in which contemporary kashrut is implicated. In investigating what Jewish tradition offers in answer to these challenges, Shoresh draws on a Jewish tradition that decentralizes institutional rabbinic authority and also pulls from a network of sources for authorizing 'eating Jewishly' as Jewish practice. Looking to 'Jewish tradition', in part, involves the historicization of kashrut. In her plenary, Risa historicizes kashrut through a narrative tracing shifts from communitybased decision-making to an industrialized system that, while offering important assurances, is costly enough to shut out small local businesses. ${ }^{29}$ Looking to 'Jewish tradition' can also consolidate that tradition itself as an apparently single and unified body of authentic Jewishness rather than as a fragmented narrative of the accidents of history.

In describing the widest possible authorizing circle in which to situate its Jewish eating practice, Shoresh has constituted 'eating Jewishly' in largest part according to a notion of what is good to do. A vision of 'the good' can be excavated through attending to which authorizing discourses (appeals to Jewishness through religion, community, ethics, culture, and so on) function to consolidate power and cultivate a community's orientation, in this case toward 'eating Jewishly'. The idea of 'eating Jewishly' we have attended to here is a departure from two major ideas about Jews and food: the idea of kashrut as the sine qua non of Jews eating in a way that connects to their Jewishness, and the idea of Jewish foods as markers of Jewish identity by participation in an historical aesthetic. Shoresh makes room for both of those things within the wider frame of 'eating Jewishly', and a large part of its reasoning is ethical.

The notion of 'eating Jewishly' offers a structure for legibility, authoritativeness, and legitimacy for food practices that fall outside current systems

29 I distinguish the question of whether kashrut should (or does) include ethical assurances, from the move to historicize. They are different issues, although they bear a relationship to one another. Historicization has been pursued in the academic literature by investigating the diversity of authorized practices between Sephardic and Ashkenazi Jewry (cf. Cooper 1993, Kraemer 2007), by exploring the practice of kashrut before the rise of Jewish Orthodoxy (cf. Cooper 1993, Kraemer 2007, Rosenblum 2010), and by attending to the history of women's power in authorizing paths of kashrut observance (cf. Abusch Magder 2005, Joselit 1996 [1994], Sered I992), as well as in the response of Reform Judaism and the industrialization of kashrut mentioned above. 
for legible, authoritative, and legitimate Jewish eating. The usual approaches have been disturbed in recent years, in the larger social response to problems of industrial food production and consumption. As problems in factory farming, agribusiness, and the industrial food system have come more and more urgently into public view, there has been an attendant crisis of faith in the industrial systems which govern kashrut, which threatened to further fragment geographies of community practice in an already fragmented, denominationalized Jewry. A new configuration of the Jewish population has emerged: a segment that crosses denominational boundaries and is unified by the concern that the systems by which food comes to them now bears little resemblance to those systems by which food came to them in the past, and that this gap is problematic for them as Jews.

Shoresh consolidates multiple threads of authorization, including orthodoxy, women's authoritative knowledge, and horizontal knowledges in Jewish traditions, Jewish lives, and the Jewish food movement. These authoritative discourses help Shoresh to develop an approach to food that displaces kashrut from the centre of Jewish eating. Kashrut is thus retained (in multiple forms including industrial and historical), reimagined (through historicization), and repositioned alongside multiple kinds of authoritative Jewish practice. Room is made for multiple legitimate 'Jewish' approaches to food practice. Community is consolidated not around adherence or non-adherence to law but rather around authoritative Jewishness, and the lines of purity are redrawn around (explicitly) ethics and (implicitly) identity.

This article has been concerned with examining the meanings given to certain food choices, and the framework according to which those food choices are made and within which those meanings are embedded. By investigating the construction of 'eating Jewishly', I have shifted focus from the question of food and Jewish identity, preferring the question of the conditions of possibility for the construction of either identity or religion. Authorizing discourses, based on a variety of Jewish sources, help us trace the lines of power according to which particular instances of identity or religion become legible, particular ideas gain traction, and particular constellations of ideas achieve cohesion. If food is a window onto life, here, 'eating Jewishly' is a window onto the ongoing construction of tradition, which is the stuff of lived religion. Authorizing discourses offer productive constraint in the formation of Shoresh's lived religion, and in the formation of religious tradition as a source for ethics. 
Aldea Mulhern is a PhD Candidate at the Department for the Study of Religion and the Centre for Jewish Studies at the University of Toronto, Canada. She works at the intersection of food and lived religion, where she investigates power, bodies, and ideas about value. Her dissertation is a comparative ethnographic analysis of the participation of two religious groups, one Jewish and one Muslim, in Toronto's food movement. She has coauthored an entry in Oxford Bibliographies Online on the topic of Judaism and food.

\section{Bibliography}

Abusch-Magder, Ruth Ann, 2005. 'Kashrut: the possibility and limits of women's domestic power', paper presented at the Fifteenth Annual Symposium of the Klutznick Chair in Jewish Civilization, held at the Harris Center for Judaic Studies, University of Nebraska-Lincoln, 27-28 October 2002, in Food and Judaism, ed. Leonard J. Greenspoon, Ronald Simkins, and Gerald Shapiro, Studies in Jewish Civilization, ${ }_{5}$ (Omaha, NE, Creighton University Press), pp. I69-92

Asad, Talal, 1993. Genealogies of Religion: Discipline and Reasons of Power in Christianity and Islam (Baltimore, Johns Hopkins University Press)

Bloom, Stephen G., 200o. Postville: A Clash of Cultures in Heartland America (New York, Harcourt)

Cooper, John, I 993. Eat and be Satisfied: A Social History of Jewish Food (Northvale, NJ, Jason Aronson)

Dallam, Marie W., 2014. 'Introduction: religion, food and eating' in Religion, Food, and Eating in North America, ed. Benjamin E. Zeller, Marie W. Dallam, Reid L. Nielson, and Nora L. Rubel (New York, Columbia University Press)

Fishkoff, Sue, 20 Io. Kosher Nation: Why More and More of America's Food Answers to a Higher Authority (New York, Schocken Books)

Gastwirt, Harold P., I 974. Fraud, Corruption, and Holiness: The Controversy over the Supervision of Jewish Dietary Practice in New York City, 1881-1940 (Port Washington, NY, Kennikat Press)

Greenspoon, Leonard J., Ronald Simkins, and Gerald Shapiro (eds), 2005. Food and Judaism (Omaha, NE, Creighton University Press)

Gross, Aaron Saul, 2010. The Question of the Animal and Religion: Dietary Practices, Subjectivity, and Ethics in Jerwish Traditions, PhD dissertation, University of California Santa Barbara

20 I I. 'Continuity and change in reform views of kashrut I 883-2002: from the T'reifah banquet to eco-kashrut' in The Sacred Table: Creating a Jewish Food Ethic, ed. Mary L. Zamore (New York, CCAR Press), pp. 235-59

Hazon, nd. 'About Hazon: history', Hazon: Jewish inspiration. Sustainible communities. <http://hazon.org/about/history/> (accessed 25.8.2014)

Hyman, Paula E., I 980 . 'Immigrant women and consumer protest: the New York City kosher meat boycott of I 902', American Jewish History, 70(I), pp. 91-I05

Informing Change, 20I4. 'Seeds of opportunity: a national study of immersive Jewish outdoor, food and environmental education (JOFEE) report, <http://hazon. 
org/wp-content/uploads/20 I 4/o2/Hazon-Report-R4-web-reduced.pdf> (accessed 25.8.2014).

Joselit, Jenna Weissman, 2005. 'Food fight: the Americanization of kashrut in twentieth century America', paper presented at the Fifteenth Annual Symposium of the Klutznick Chair in Jewish Civilization, held at the Harris Center for Judaic Studies, University of Nebraska-Lincoln, 27-28 October 2002, in Food and Judaism, ed. Leonard J. Greenspoon, Ronald Simkins, and Gerald Shapiro, Studies in Jewish Civilization, I 5 (Omaha, NE, Creighton University Press), pp. $335^{-45}$

Joselit, Jenna Weissman, 1996 ( I 994). The Wonders of America: Reinventing Jerwish Culture 1880-1950 (New York, Hill and Wang)

Kraemer, David Charles, 2007. Jewish Eating and Identity Through the Ages (New York, Routledge)

Lugo, Louis, et al., 2013. A Portrait of Jewish Americans: Findings from a Pew Research Center Survey of U.S. Jews (Washington, DC, Pew Research Center, <http:// www.pewforum.org/files/2013/10/jewish-american-full-report-for-web.pdf > (accessed 25.8.2014)

Lytton, Timothy D., 201 3. Kosher: Private Regulation in the Age of Industrial Food (Cambridge, MA, Harvard University Press)

-2014. 'Jewish foodways and religious self-governance in America: the failure of communal kashrut regulation and the rise of private kosher certification, The Jewish Quarterly Review, I04(I), pp. 38-45

Magen Tzedek, nd. 'An ethical certification of food', The Magen Tzedek Standard <http://www.magentzedek.org/> (accessed 25.8.2014)

Most, Andrea, forthcoming 2015. 'The farmer's in the Shul: the contemporary Jewish food movement in North America: a report from the field(s)', Studies in Contemporary Jewry 28

Most, Andrea, and Aldea Mulhern, 20 I 4. 'Food', Oxford Bibliographies Online: Jewish Studies, doi: 10.1093/obo/978019984073 I-0067

Nakhimovsky, Alice Stone, 2005. 'Public and private in the kitchen: eating Jewish in the Soviet state' in Food and Judaism, ed. Leonard J. Greenspoon, Ronald Simkins, and Gerald Shapiro, Studies in Jewish Civilization, I 5 (Omaha, NE, Creighton University Press), pp. I49-67

Pollan, Michael, 2o го. 'The food movement, rising', The New York Review of Books, ro, pp. I $^{\mathrm{I}-3}$, <http://michaelpollan.com/articles-archive/the-food-movementrising/> (accessed 25.8.2014)

Rosenblum, Jordan D., 20I0. Food and Identity in Early Rabbinic Judaism (Cambridge University Press)

Sarna, Jonathan D., 2004. American Judaism: A History (New Haven, Yale University Press)

Savage, Nigel, and Anna Hanau, 2007. Food for Thought: Hazon's Sourcebook on Jerws, Food E Contemporary Life (New York, Hazon) 
Sered, Susan Starr, 1992. Women as Ritual Experts: The Religious Lives of Elderly Jerwish Women in Jerusalem (New York, Oxford University Press)

Shoresh, nd. Shoresh Jewish Environmental Programs, <http://shoresh.ca/> (accessed 25.8.2014)

Shoresh Blog, <http://shoreshprograms.blogspot.ca/> (accessed 25.8.2014)

Union for Reform Judaism, nd. Eating Jewishly: Union for Reform Judaism's $70^{\text {th }}$ General Assembly. URJ Resolution, <http://urj.org/about/union/governance/ reso/?syspage $=$ article\&item_id $=27522>($ accessed 25.8.20 I 4 $)$

Zamore, Mary L. (ed.), 20 I I. The Sacred Table: Creating a Jerwish Food Ethic (New York, CCAR Press)

Zeller, Benjamin E., Marie W. Dallam, Reid L. Nielson, and Nora L. Rubel (eds), 201 4. Religion, Food, and Eating in North America (New York, Columbia University Press) 